\title{
SPATIAL ANALYSIS OF YAMPIL BARROW COMPLEX
}

\begin{abstract}
The Yampil Region represents a concentration of densely populated barrow cemeteries. Some 156 mounds figure in the available cartographic studies, which are the basis of spatial analysis presented below. The aforementioned therefore shall involve an examination of parameters for the localisation of tumuli in respect to altitude, terrain surface incline, direction of exposition and distance from waterways and watershed ridges as well as an analysis of visibility for selected sites, which shall describe preferences in respect to the chosen place of construction.
\end{abstract}

ABSTRACT

Key words: spatial analysis, Dniester, Eneolithic, Bronze Age

INTRODUCTION

The Yampil Region lies on the southern edge of the Podolia Upland, in the drainage basin of the Middle Dniester (Fig. 1). The loess substrata here represents

\footnotetext{
* k.jachimowicz89@gmail.com

** Department of Prehistory of Central and Eastern Europe, Institute of Archaeology, Adam Mickiewicz University, Umultowska 89D, 61-614 Poznań, Poland; danuta@amu.edu.pl
} 


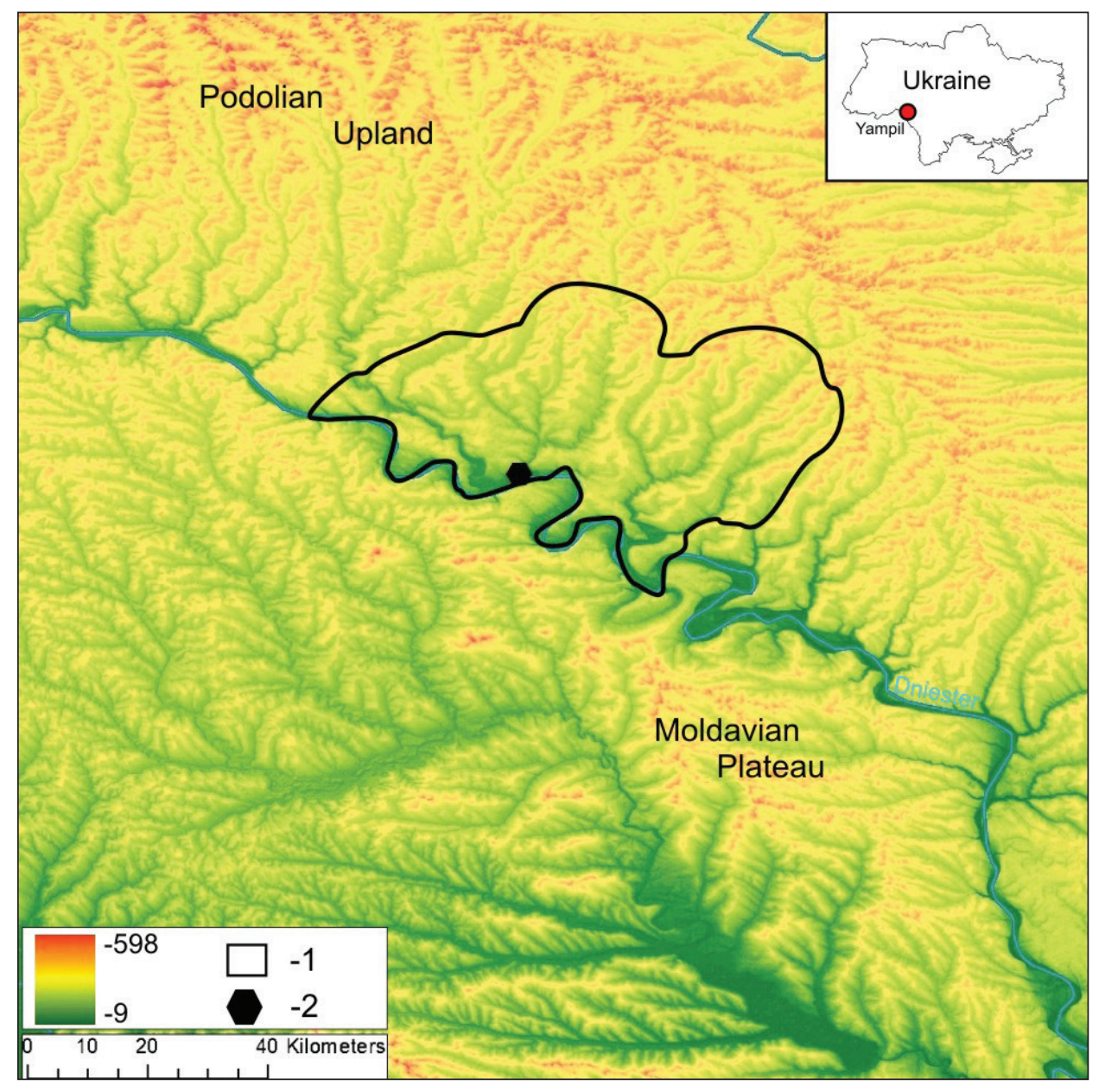

Fig . 1. Location of research area: 1 - Yampil Region border; 2 - Yampil

the major scale of studies in this area, which to a significant degree impact on the landscape profile. In the general geomorphological context, the Yampil Region can be said to be in the category of flat and undulating planes of an alluvial and delluvial origin. In respect to climate and flora the subject of study lies in the forest steppe belt - a transitory area between the forest zone and the steppe. The native flora that is characteristic for this terrain is one of oak forests, meadow and stipa grass steppes [Makohonienko, Hildebrandt-Radke 2014; Kusiński, Zastawnyj 2003].

The modern-day landscape of the area under study, combining the traits forming the terrain and its flora, allows for the reading of its particular properties. From the moderate rises of the region vast areas are visible towards a horizon many tens of kilometres away in the distance. 
Ta b I e 1 Yampil Barrow Cemetery Complex: excavation in 2010-2012 and 2014 research results marked in gray.

\begin{tabular}{|c|c|c|c|c|c|c|c|c|c|c|}
\hline Item & Site & 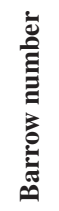 & 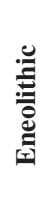 & 䨔 & 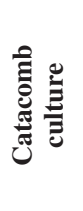 & 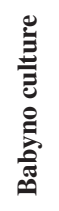 & 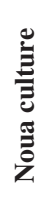 & $\begin{array}{l}\underbrace{\infty}_{0} \\
0 \\
0\end{array}$ & 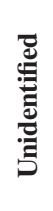 & 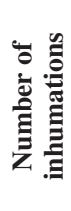 \\
\hline 1 & Dobrianka & 1 & & 5 & & 6 & & & & 11 \\
\hline 2 & Porohy & 1 & & 2 & & & & & & 2 \\
\hline 3 & Porohy & 2 & & 4 & & & & 2 & & 6 \\
\hline 4 & Porohy & 3 & & 2 & & 5 & & 1 & 1 & 9 \\
\hline 5 & Porohy & $3 \mathrm{~A}$ & 7 & 10 & & & 4 & 1 & & 22 \\
\hline 6 & Porohy & 4 & & 1 & & 4 & & 3 & 1 & 9 \\
\hline 7 & Pysarivka & 1 & & 2 & & & & & & 2 \\
\hline 8 & Pysarivka & 2 & & 1 & & & & 2 & & 3 \\
\hline 9 & Pysarivka & 3 & & 3 & & & & 1 & 1 & 5 \\
\hline 10 & Pysarivka & 4 & & 2 & & & & & & 2 \\
\hline 11 & Pysarivka & 5 & & 1 & & 1 & & 1 & & 3 \\
\hline 12 & Pysarivka & 6 & & 3 & & & & 1 & & 4 \\
\hline 13 & Pysarivka & 7 & & 1 & & 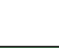 & & 2 & 2 & 5 \\
\hline 14 & Pysarivka & 8 & & 1 & & 1 & & & 2 & 4 \\
\hline 15 & Pysarivka & 9 & & 2 & & 1 & & & 1 & 4 \\
\hline 16 & Severynivka & 1 & & 1 & & 1 & & 2 & 2 & 6 \\
\hline 17 & Severynivka & 2 & & 11 & & 1 & & 1 & & 13 \\
\hline 18 & Pidlisivka & 1 & 3 & 4 & 2 & 2 & & 1 & 1 & 13 \\
\hline 19 & Klembivka & 1 & 3 & & & 6 & 4 & & 2 & 15 \\
\hline 20 & Prydnistryanske & I & 1 & & 1 & & & 2 & & 4 \\
\hline 21 & Prydnistryanske & II & 2 & & & & & & 1 & 3 \\
\hline 22 & Prydnistryanske & III & 2 & & & & & 1 & & 3 \\
\hline 23 & Prydnistryanske & IV & 2 & 5 & & & & 2 & 1 & 10 \\
\hline & & & 20 & 61 & 3 & 28 & 8 & 23 & 15 & 158 \\
\hline
\end{tabular}




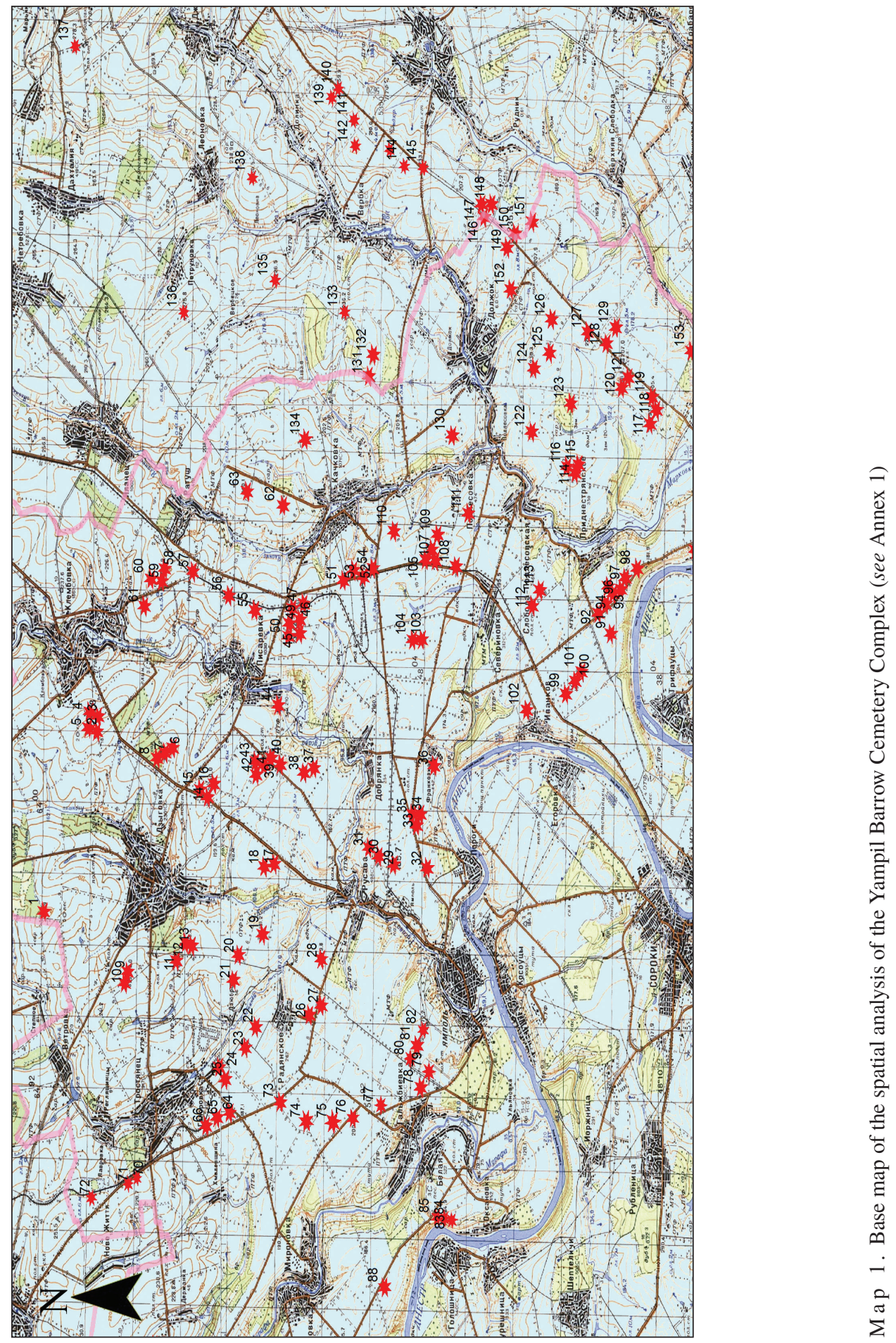




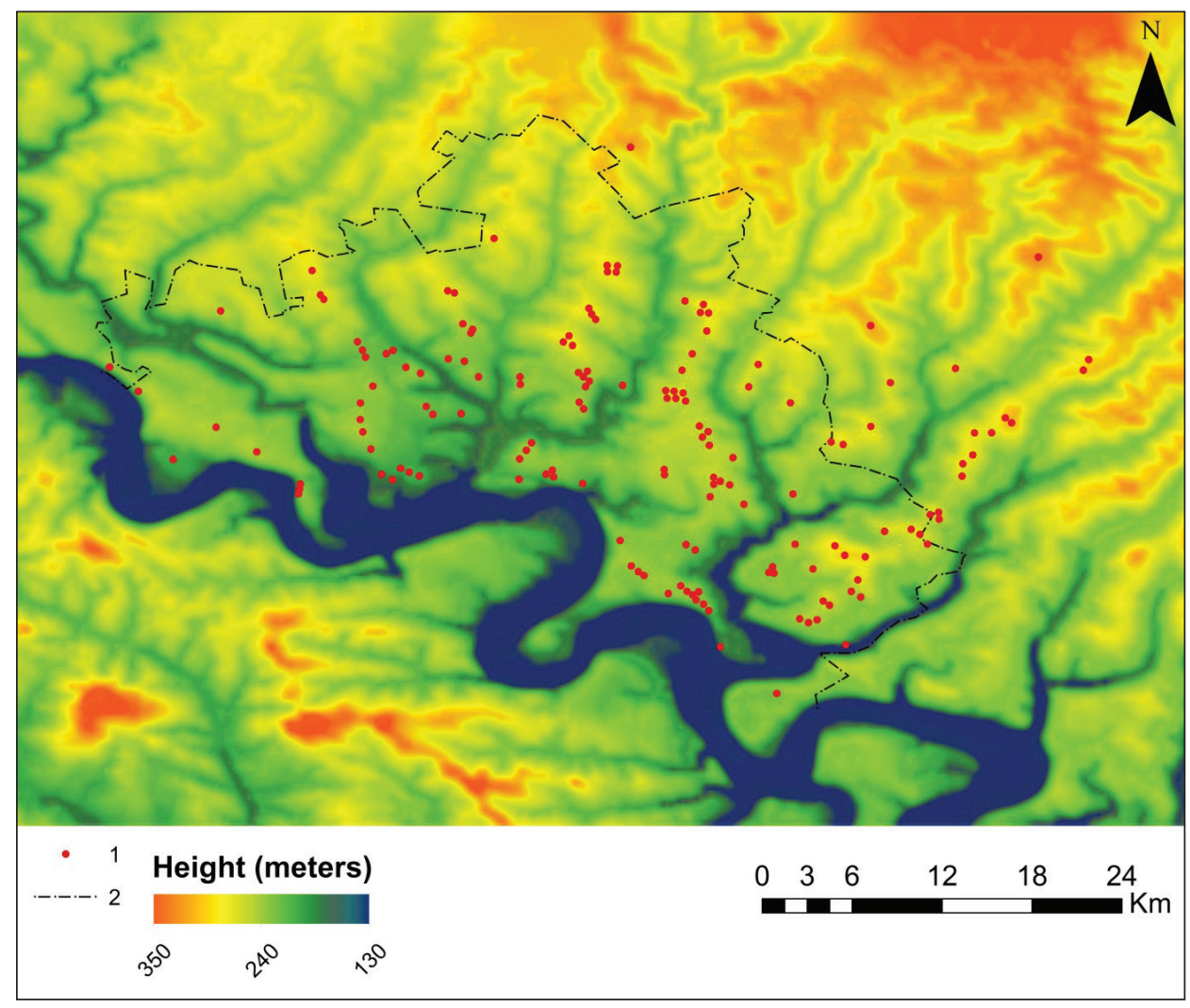

Fig. 2. Yampil barrow cemetery complex: digital elevation model for studied area. 1 - barrows, 2 - borders of the Yampil Region

The hydrographical network of the Yampil Region is made up by the left bank tributaries of the Dniester, which in part demarcates the southern administrative border of the Yampil Region and the territory of Ukraine.

1. MATERIALS

A conservation study of the Yampil Region has produced a topographical map in the scale of 1:100,000 featuring identified barrows in the area [Potupczyk, Razumow 2014], which constitutes the basis of spatial analysis that was conducted. Its publication in 2010 did not entail any new discoveries [Przybyła et al. 2017]. In the area under study within the administrative borders of the Yampil Region, measur- 


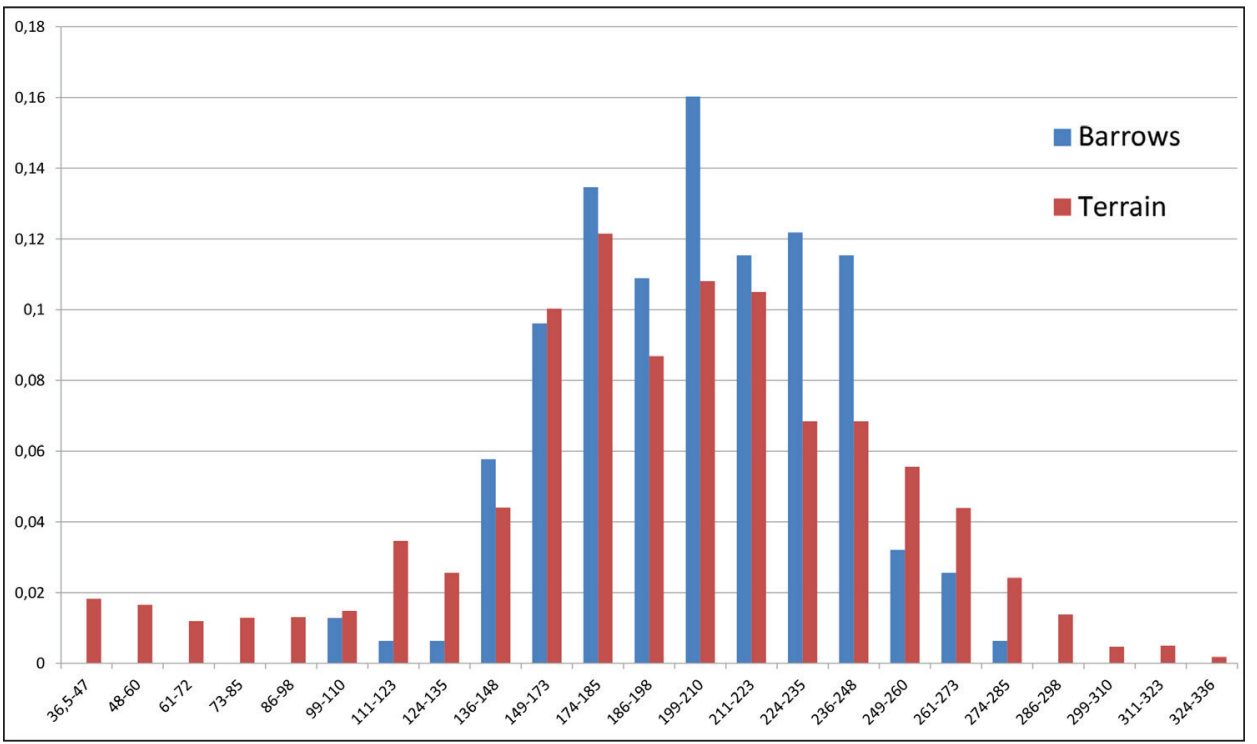

Fig. 3. Yampil barrow cemetery complex: percentage distribution of barrows and surface area in the altitude categories established above sea level.

ing some $790 \mathrm{~km}^{2}$, there have been recorded thus far 156 tumuli (approximately 0.2 per $\mathrm{km}^{2}$ ). Only 23 so far (approximately $15 \%$ ) have been verified in the context of excavation research. Their characteristics are presented in Tab. 1. Four of the sites studied by the Polish-Ukrainian expedition in the period 2010 to 2014 have been subjected to more detailed analysis of their location in the context of data gained for the entire barrow cemetery complex [Kośko 2015].

2. METHODS

Spatial analysis was conducted on the basis of the Digital Elevation Model (DEM) created using a topographical map in the scale of 1: 100,000 (Map 1 and Fig. 2) [Placek 2008; Jaskulski, Szmidt 2013]. This map also served to create a vector layer that defined the location of barrows. The following were taken into consideration or parameters describing the locus of sites studied: terrain incline, slope exposition as well as distance from river valleys and watershed ridges. The ArcMap 10.2 application, part of the ArcGis software, created by ESRI (Environmental Systems Research Institute) [Litwin, Myrda 2005] was used to record the analysis below. All analysed parameters are given in Annex 1. 


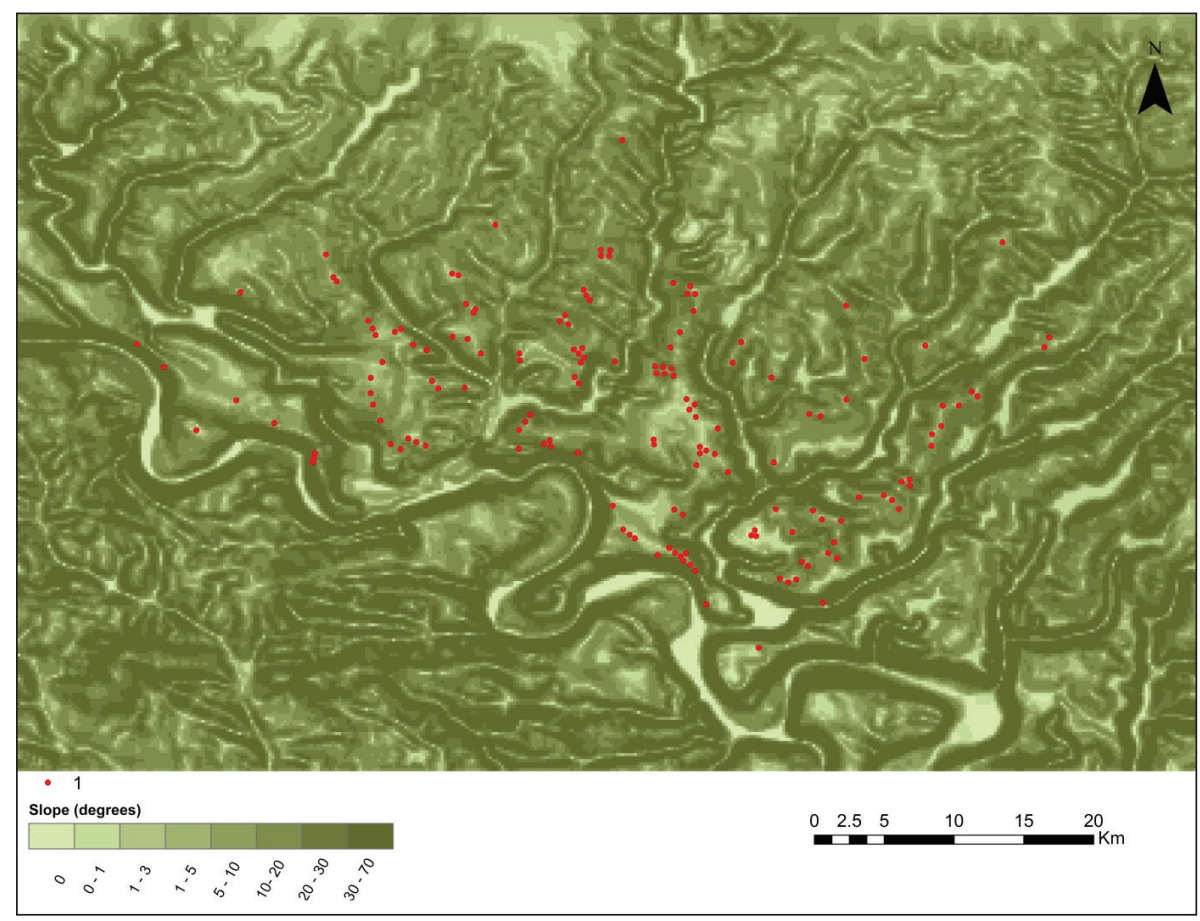

Fig. 4. Yampil barrow cemetery complex: map of slope incline of the terrain under study. 1 - barrows

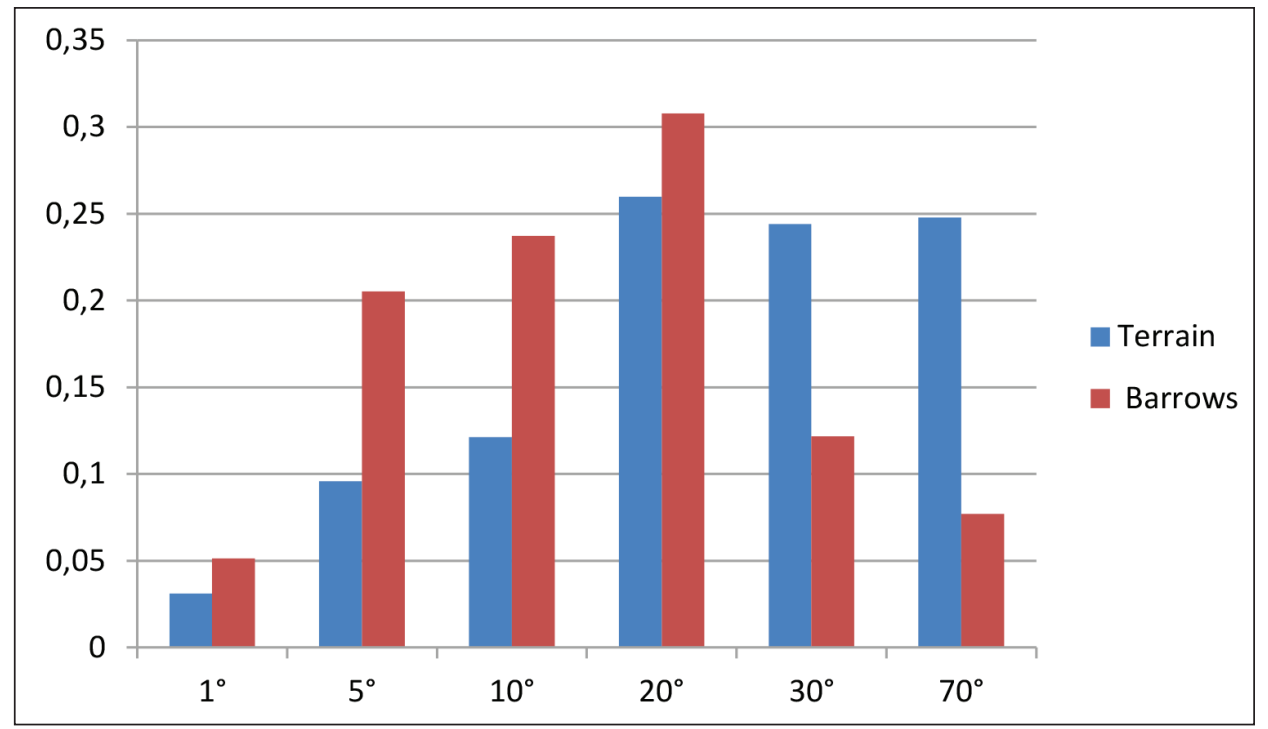

Fig. 5. Yampil barrow cemetery complex: percentage distribution of barrow number and terrain surface for established categories 


\section{ALTITUDE ABOVE SEA LEVEL}

The terrain under study is characterised by marked differences in relative altitude. The lowest placed areas are those in the Dniester Valley (to $36 \mathrm{~m}$ a.s.l.). The highest measurements reaching $349 \mathrm{~m}$ are recorded on the upland in the northern part of the area under study. As far as the topography is concerned, there is a domination of terrain situated at an altitude between hundred and 49 to $248 \mathrm{~m}$. In this category some $66 \%$ of the surface area studied is found and $86 \%$ of barrows (Fig. 3).

The location of particular mounds in terms of altitude above sea level in general represents the nature of the terrain as such. The highest placed mound $-283 \mathrm{~m}$ a.s.l. - is found in the north-east end of the area under study, near the town of Horodkiv. The lowest placed on the other hand, is the mound near Velyka Kisnytsya, almost $100 \mathrm{~m}$ a.s.l. The majority of barrows under study $-86 \%$ - are situated in the category of 149-248 $\mathrm{m}$ a.s.l.

The excavated sites relate to the category that groups the greatest number of mounds located at a altitude between 140 and $244 \mathrm{~m}$. Amongst this group the lowest situated are the sites in Porohy and Prydnistryanske (163 and $193 \mathrm{~m}$ a.s.l.), Whilst the highest located features are found in Pidlisivka and Klembivka (201 and $242 \mathrm{~m}$ a.s.1.).

\section{TERRAIN SURFACE INCLINE}

An analysis of the terrain surface incline map shows that the greatest degree of incline relates to the slope of the Dniester Gorge (up to $68^{\circ}$, Fig. 4). Such a high degree of incline can be also observed on the valley slopes of this river's tributaries. One half $(50.8 \%)$ of the terrain under study shows a small incline between 0 to 20 degrees, where over $80 \%$ of tumuli are found (Fig. 5).

The topography of barrows in the context of landscape incline suggests quite clearly that these tumuli were located on a terrain with a low incline. There are however, a small number of sites that appear to be situated in areas of high parameters in this context (above 20 - Fig. 5). Moreover, the presence of barrows in the last two categories gives one cause for further reflection. This is a result of the fact that inasmuch as a terrain with a 30 to $40^{\circ}$ incline physically is suitable for the filling of a mound, areas of a higher parameter in this context would appear to be exceptionally difficult ones in which to undertake such work. First and foremost, the rather large scale of the source map has had an influence in this regard on the 


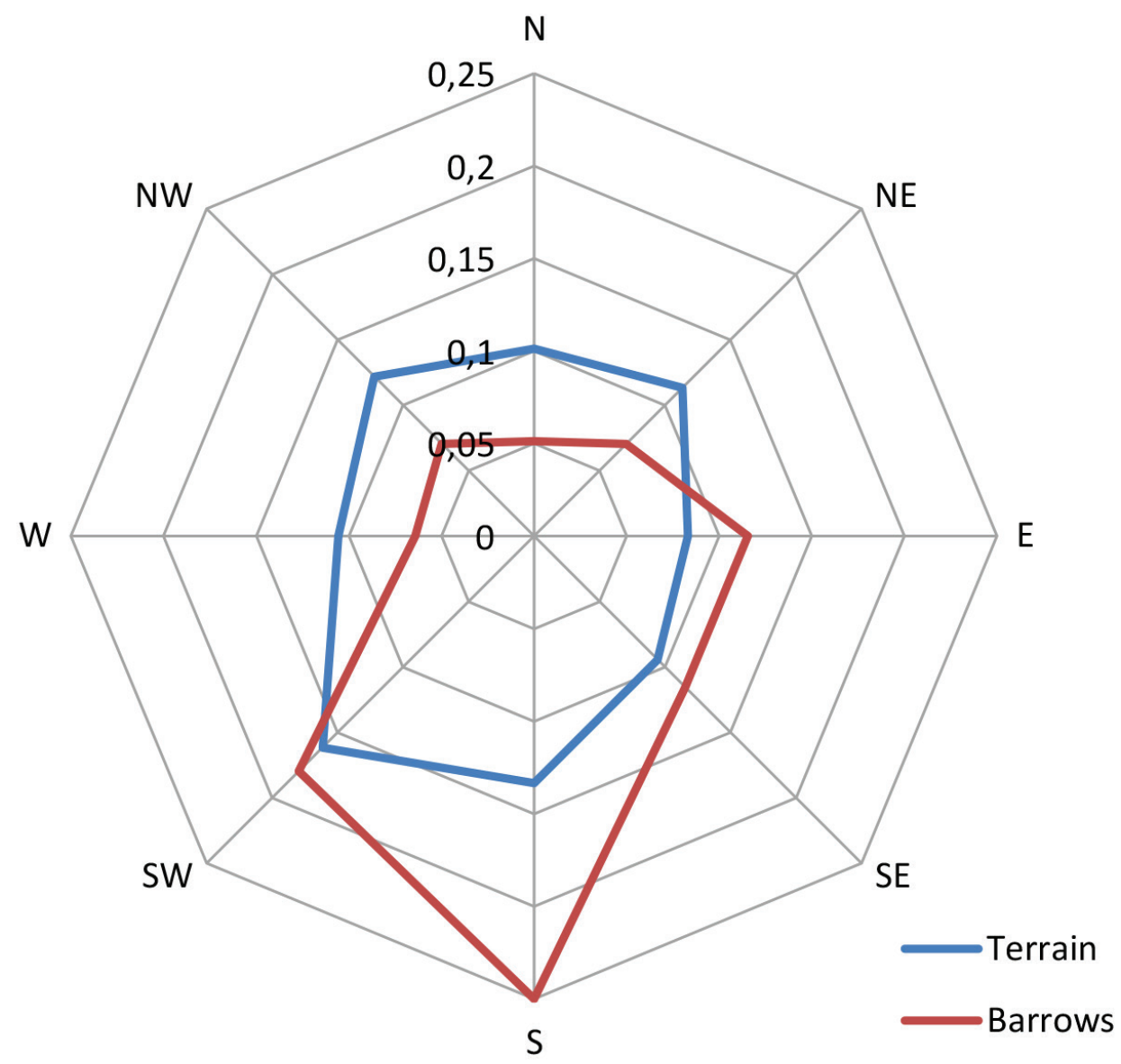

Fig . 6. Yampil barrow cemetery complex: distribution of terrain surface and tumuli for geographical direction

research results. In order to improve these it would be necessary to create a digital altitude model for the use of maps with a decidedly lower scale, which would reduce the risk of error.

The sites subjected to excavation research show small amounts of the parameter in question. In this regard the terrain incline read from the base map does not exceed $13^{\circ}$ in any of the cases (Porohy - see Annex 1). 


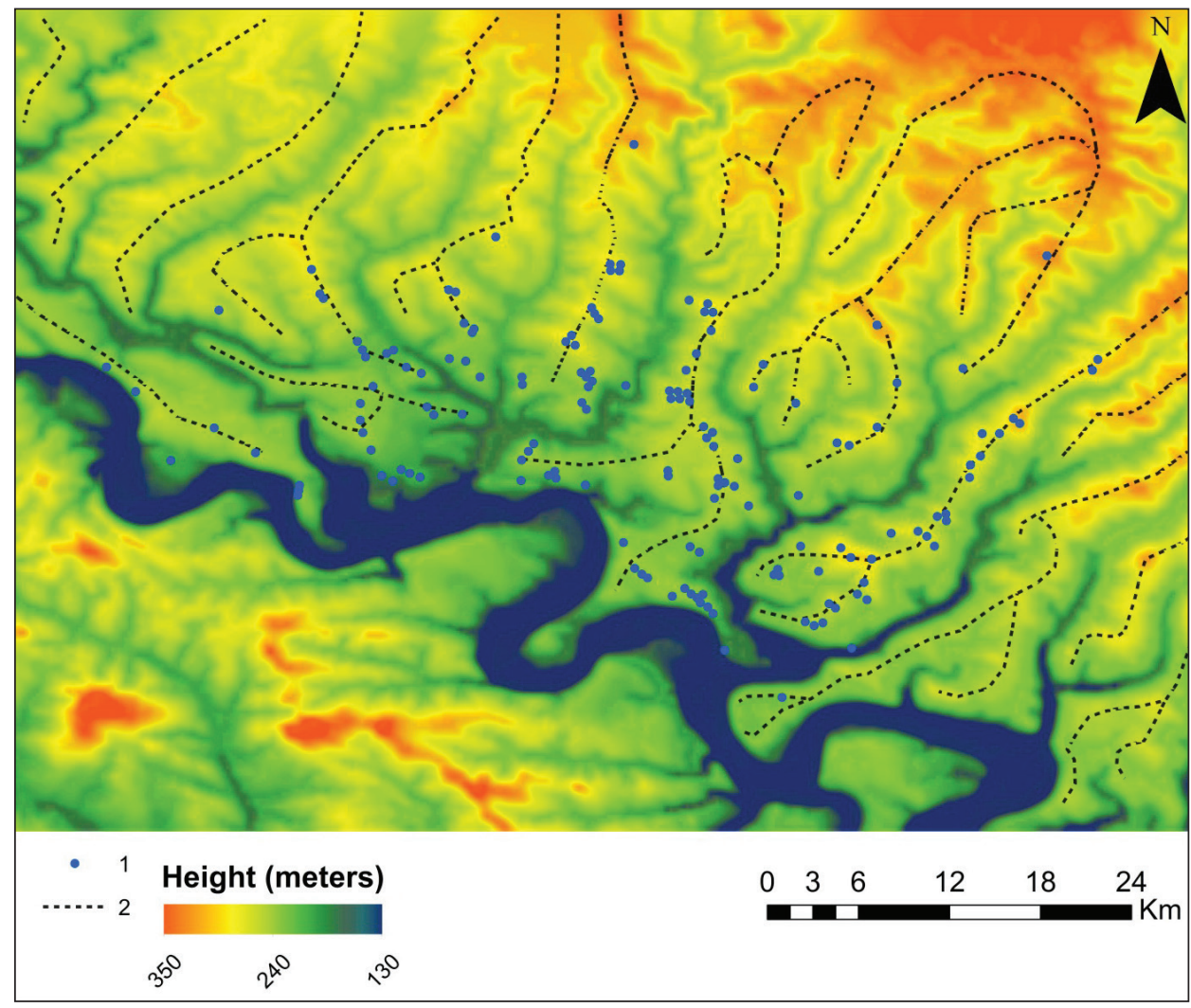

Fig. 7. Yampil barrow cemetery complex: marked watershed ridges of the terrain under study in terms of the altitude model. 1 - barrows, 2 - watershed ridges

\section{EXPOSITION DIRECTION}

An analysis of topography relating to the sites mentioned in the context of this research aspect is difficult on account of its low readability. This is caused by the differentiated nature of terrain profile in the area studied. Steep river valleys - both the Dniester and its tributaries as well as the numerous hills on watersheds result in a large differentiation of the parameter mentioned. Thus, a description of the usefulness in respect to the exposition parameter in the present discussion needs to take place on the basis of a graph that shows what number of tumuli are situated on inclined slopes in a specific direction (Fig. 6).

The area described as flat combines a mere $8.5 \%$ of the terrain surface under study, where 12 barrows are found $(8 \%)$. The remaining directions of slope incline 
in the area under study are broken down rather equally, accepting values oscillating between 10 and $15 \%$ of terrain surface.

In terms of mound topography therefore, there is a tendency for the avoidance of prominent slopes in a northerly direction and preferences for a southern and southern-western direction.

\section{DISTANCE FROM WATERWAYS AND WATERSHED RIDGES}

The creation of river layers took place through the vectorisation of waterways lines, based on the map in the scale of 1:100,000. So as to mark the line of watershed ridges on the basis of a digital altitude model a layer of surface flow directions was created, using the Flow Direction module, ArcMap application. Subsequently, the halftone that arose as a result of this process was transformed by the Flow Accumulation module. As a result, a map was created, which showed the accumulation of surface flow for every one of the units. On this basis watershed ridges were marked, creating a line in places where the relevant units took on the value 0 (Fig. 7). Naturally, the remaining lines were drawn far more simply so that the network of ridges was not overly dense.

The decided majority of the barrows found is placed at a distance from rivers in the range of 1001 two $4000 \mathrm{~m}(89 \%$ sites, Figs. 8, 9). In this context, the most predominant range of distance is from 2001 to $3000 \mathrm{~m}$, covering as much as $39 \%$ of sites. This particular state of affairs allows one to propose that the location of barrows in respect to the Yampil Complex was not related to the immediate proximity of rivers.

The chart of distribution for percentage distance from watershed ridges shows that over $77 \%$ of barrows (121 mounds) are found at a distance up to $1000 \mathrm{~m}$ from the watershed ridge.

In respect to the entire above group there can be seen a clear preference for the location of barrows within watershed ridges and at the same time, an avoidance of locating tumuli in the immediate neighbourhood of waterways. 


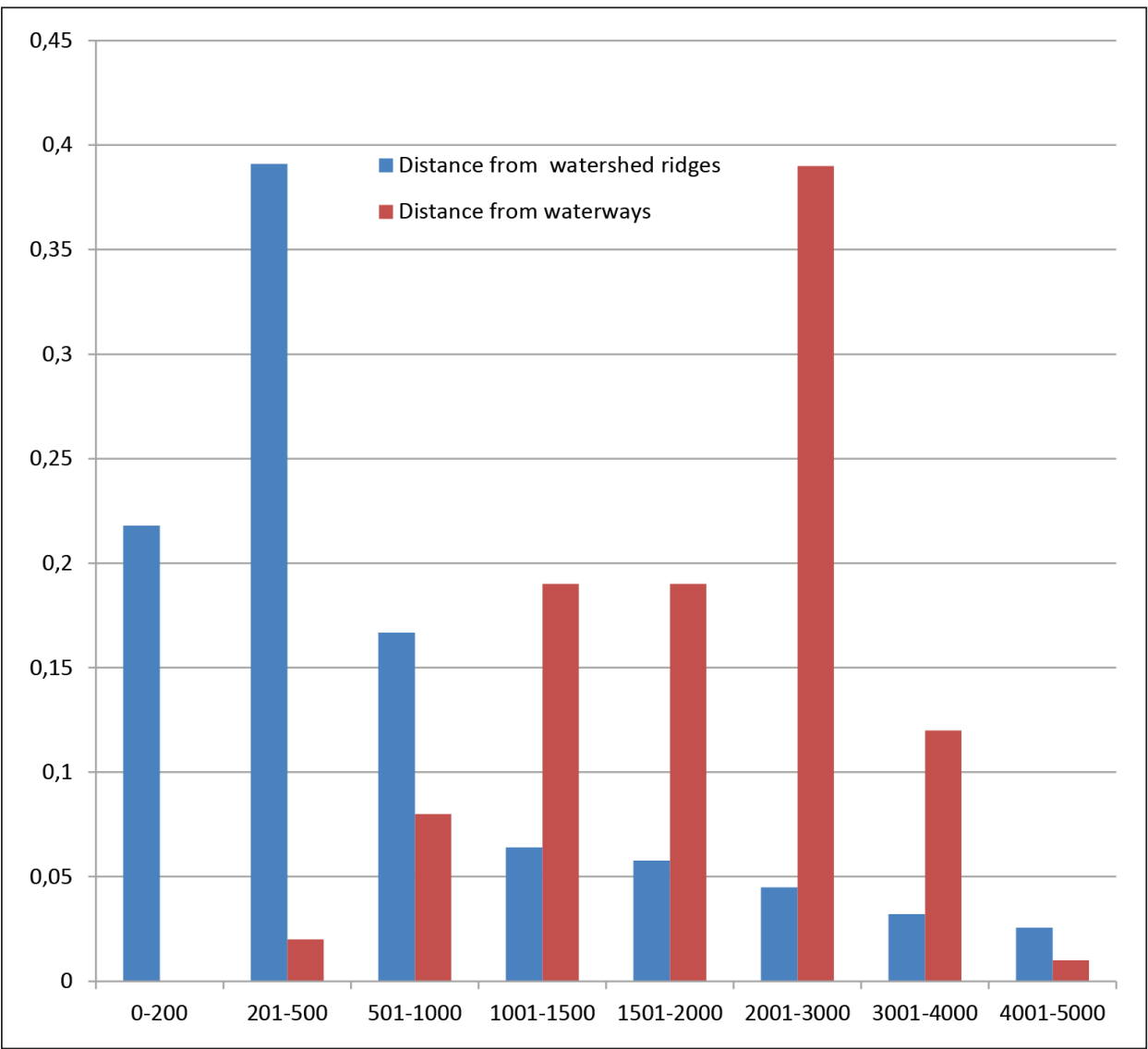

Fig . 8. Yampil barrow cemetery complex: distribution of tumuli number and terrain surface for accepted categories of distance from watershed ridges and waterways

\section{ANALYSIS OF VISIBILITY}

The visibility of barrows is considered to be one of the significant aspects for the choice of a place for their location [Ślusarska 2011]. In a subsequent analysis a simulation was conducted for the visibility of excavated barrows. For these purposes a buffer with a diameter of $2200 \mathrm{~m}$ for each of the tumuli was marked in which a zone was delineated, where a given mound was visible for an observer of $1.7 \mathrm{~m}$ [Weathley 1995].

The mound at the site in Pidlisivka, within the buffer measuring $2200 \mathrm{~m}$ in diameter, would only be visible from $15 \%$ of this surface area, concentrated mainly in a western and north-western direction (Fig. 10: 1). With a broadening of the 


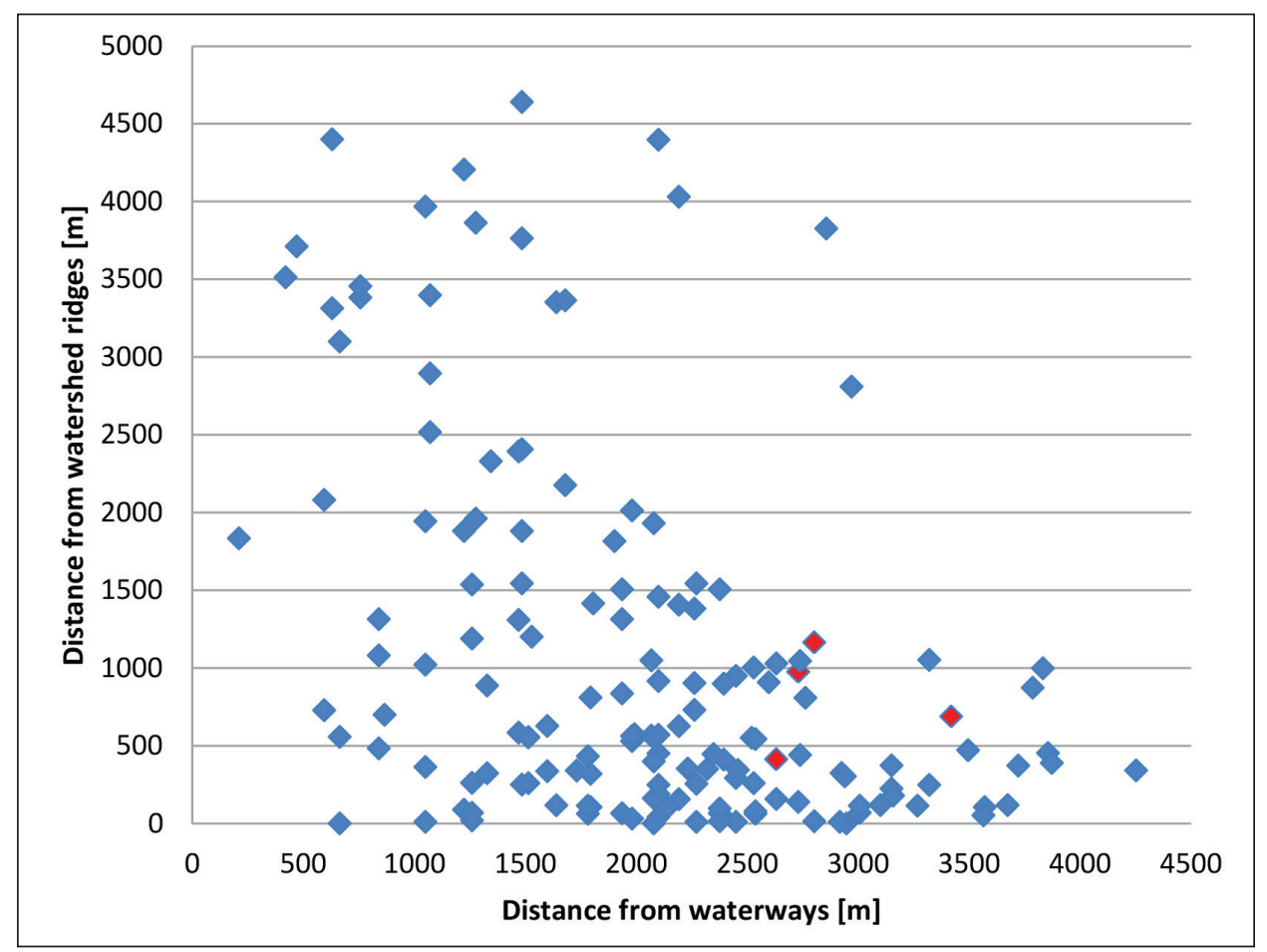

Fig. 9. Yampil barrow cemetery complex: the location of particular barrows for distance from waterways and watershed ridges. Sites excavated are mark in red

zone, from which the tumulus in Pidlisivka would be visible, it is possible to note that these areas combine in a decidedly eastern and southern direction from the site in question. Within their area some 35 barrows were found from this region, which may be interpreted as an indicator of the potential visibility from 35 other barrow mounds in Pidlisivka. This provides a picture of the spatial grouping of these mounds - generation of concentrations that based on the parameter of visibility can create a genus of mutually related local units (chronological?; regional?).

The site in Porohy in direct proximity of the barrow (buffer measuring a diameter of $2220 \mathrm{~m}$ ) would be visible from a small fragment of area located west of the barrow, taking up 12\% of the surface (Fig. 10: 2). The factor analysed, however, begins to increase in respect to distance from the site, where areas with a view of the mound group in particular on the opposite line of the Dniester. Within the bounds of areas from which it is possible to notice the mound in Porohy, merely 15 other tumuli were found, which to a large extent is related to the significant occurrence of areas from which it is possible to see the mound in Porohy on the other side of the Dniester and therefore in areas for which we do not have barrows located. 


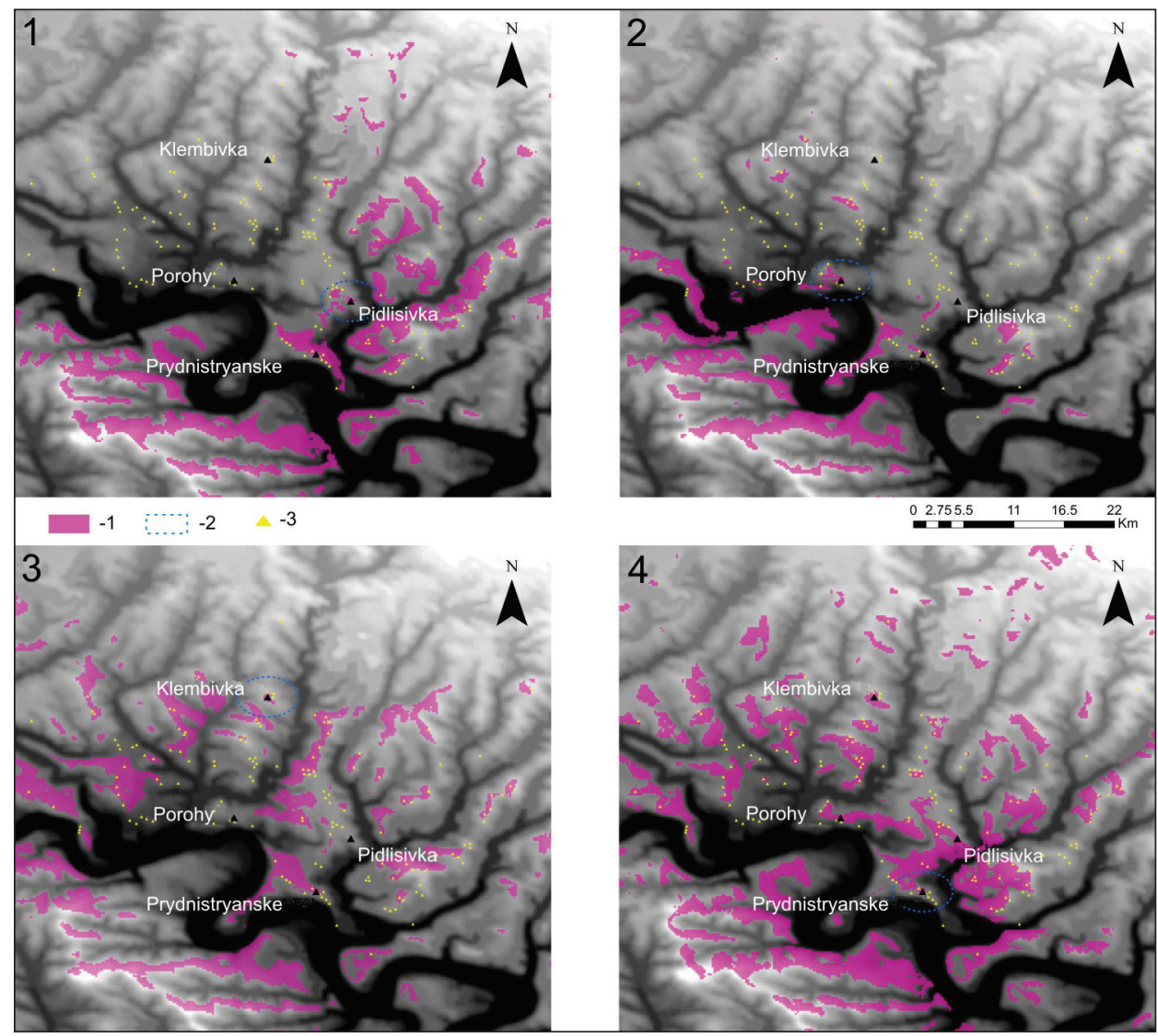

Fig. 10. Yampil barrow cemetery complex: analysis of visibility at the site in Pidlisivka (1), Porohy (2), Klembivka (3) and Prydnistryanske (4). 1 - areas from which the analyzed barrow was visible, 2 - buffer measuring a diameter of $220 \mathrm{~m}, 3$ - remaining barrows

The barrow in Klembivka, in the outline of its buffer, is merely visible from $10 \%$ of the area (Fig. 10: 3). From a greater distance, analysis shows its visibility to be concentrated mainly along the tributaries of the Dniester, where 52 other barrows were found.

Within the immediate surrounds of the tumulus in Prydnistryanske only $15 \%$ of the terrain demonstrates the possibility of seeing its placement (Fig. 10: 4). By increasing the distance of these areas, from which it is potentially possible to see the tumulus, there are compact areas placed here and there on the opposite side of the Dniester and its tributaries that are visible.

In summarising the results of this analysis is possible to suggest that if the criterion of barrow visibility was in fact important for the creators of these assumptions it was related to significant distances. 
Taking into account the limitations of data used in presenting the above analysis, it is possible to cautiously draw several general conclusions in respect to the preferences of Yampil barrow constructors as to the choice of location. Here, areas placed at a high altitude with the lowest possible terrain incline were chosen, whereby the exposition direction was focused towards the south and south-west. One significant parameter over and above these criteria is the distance of mounds from waterways and watershed ridges, where the latter would appear to be extremely relevant. As far as the visibility of the tumulus in the surrounding landscape is concerned, it would appear that for its constructors the visibility of the barrow was important from a greater distance, which could serve the network of 'connection' in the context of the entire studied region.

For the purposes of this research project a spatial analysis of barrow culture would also be of particular interest, where a particular group rather clearly is differentiated in respect to the average values of parameters analysed. 
ANNEX 1. VALUES OF ANALYSED PARAMETERS FOR THE YAMPIL BARROW CEMETERY COMPLEX

\begin{tabular}{|c|c|c|c|c|c|c|c|c|c|}
\hline 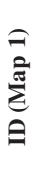 & 它 & 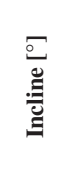 & 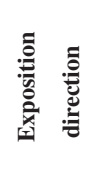 & 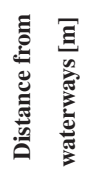 & 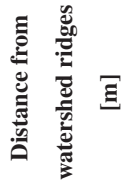 & 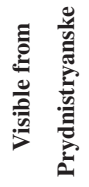 & 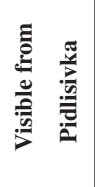 & 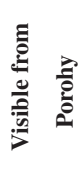 & 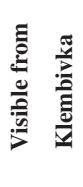 \\
\hline 0 & 269,1 & 18,7 & SW & 2802 & 1164 & 1 & 0 & 0 & 0 \\
\hline 1 & 241,1 & 4,4 & $S$ & 3418 & 689 & 0 & 0 & 0 & 1 \\
\hline 2 & 243,7 & 8,7 & $\mathrm{E}$ & 2631 & 412 & 1 & 0 & 0 & 1 \\
\hline 3 & 238,9 & 10,3 & Flat & 2730 & 976 & 0 & 0 & 0 & 0 \\
\hline 4 & 237,0 & 15,2 & $S$ & 2597 & 908 & 0 & 0 & 0 & 0 \\
\hline 5 & 252,5 & 10,4 & SW & 2271 & 255 & 1 & 0 & 0 & 1 \\
\hline 6 & 229,2 & 26,9 & $\mathrm{NE}$ & 3786 & 873 & 1 & 0 & 0 & 0 \\
\hline 7 & 242,3 & 14,7 & S & 3495 & 471 & 1 & 0 & 0 & 0 \\
\hline 8 & 244,3 & 4,9 & SW & 3100 & 118 & 0 & 0 & 0 & 1 \\
\hline 9 & 231,7 & 2,5 & $S$ & 3855 & 453 & 0 & 0 & 0 & 1 \\
\hline 10 & 231,7 & 1,2 & SW & 3673 & 118 & 0 & 0 & 0 & 1 \\
\hline 11 & 205,9 & 13,4 & SW & 2730 & 138 & 1 & 0 & 0 & 1 \\
\hline 12 & 200,9 & 3,1 & S & 2100 & 189 & 1 & 0 & 0 & 1 \\
\hline 13 & 195,8 & 15,8 & E & 2100 & 41 & 1 & 0 & 0 & 0 \\
\hline 14 & 237,9 & 15,9 & SW & 3320 & 248 & 1 & 0 & 1 & 0 \\
\hline 15 & 241,4 & 19,2 & $\mathrm{NE}$ & 3267 & 114 & 0 & 0 & 0 & 0 \\
\hline 16 & 241,8 & 5,0 & W & 3872 & 389 & 1 & 0 & 1 & 0 \\
\hline 17 & 181,3 & 6,1 & Flat & 1224 & 1881 & 0 & 0 & 0 & 0 \\
\hline 18 & 182,2 & 5,3 & Flat & 1277 & 1961 & 0 & 0 & 0 & 0 \\
\hline 19 & 180,3 & 7,4 & $S$ & 1071 & 2517 & 1 & 0 & 0 & 0 \\
\hline 20 & 177,0 & 9,1 & Flat & 1485 & 1881 & 0 & 0 & 0 & 0 \\
\hline 21 & 175,2 & 27,4 & SW & 594 & 2081 & 0 & 0 & 0 & 0 \\
\hline 22 & 180,2 & 20,0 & S & 664 & 0 & 0 & 0 & 0 & 1 \\
\hline 23 & 167,6 & 18,7 & SW & 1050 & 10 & 0 & 0 & 0 & 0 \\
\hline 24 & 156,3 & 22,1 & $\mathrm{NE}$ & 594 & 728 & 0 & 0 & 0 & 0 \\
\hline 25 & 164,3 & 1,1 & SW & 1050 & 363 & 0 & 0 & 0 & 0 \\
\hline 26 & 167,2 & 6,9 & $\mathrm{~S}$ & 2271 & 10 & 1 & 0 & 0 & 1 \\
\hline 27 & 161,5 & 16,6 & Flat & 2100 & 450 & 0 & 0 & 0 & 0 \\
\hline
\end{tabular}




\begin{tabular}{|c|c|c|c|c|c|c|c|c|c|}
\hline 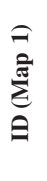 & 它 & 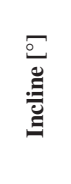 & 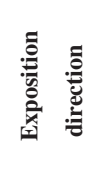 & 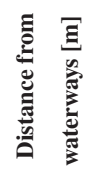 & 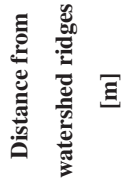 & 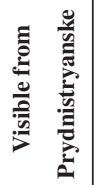 & 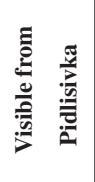 & 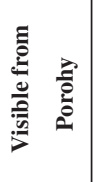 & 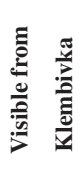 \\
\hline 28 & 150,7 & 7,8 & NW & 1224 & 88 & 0 & 0 & 0 & 0 \\
\hline 29 & 187,1 & 16,4 & SW & 1936 & 65 & 0 & 0 & 0 & 0 \\
\hline 30 & 193,3 & 5,1 & SW & 1514 & 554 & 1 & 0 & 0 & 0 \\
\hline 31 & 174,9 & 41,8 & W & 840 & 1081 & 0 & 0 & 0 & 0 \\
\hline 32 & 146,6 & 27,2 & $\mathrm{~N}$ & 1806 & 1415 & 0 & 0 & 1 & 0 \\
\hline 33 & 163,1 & 33,0 & NW & 1328 & 887 & 0 & 0 & 1 & 0 \\
\hline 34 & 168,0 & 33,3 & SE & 1050 & 1021 & 0 & 0 & 0 & 0 \\
\hline 35 & 180,0 & 13,5 & Flat & 1470 & 584 & 1 & 0 & 1 & 0 \\
\hline 36 & 142,8 & 32,5 & $\mathrm{~N}$ & 840 & 1314 & 0 & 0 & 0 & 0 \\
\hline 37 & 189,7 & 18,7 & SE & 1071 & 2895 & 1 & 0 & 0 & 0 \\
\hline 38 & 191,9 & 8,2 & SE & 1470 & 2393 & 0 & 0 & 0 & 0 \\
\hline 39 & 185,0 & 17,8 & NW & 1345 & 2330 & 1 & 0 & 0 & 0 \\
\hline 40 & 195,3 & 23,2 & NW & 1485 & 2407 & 1 & 0 & 0 & 0 \\
\hline 41 & 203,3 & 7,9 & $\mathrm{NE}$ & 2079 & 1931 & 1 & 0 & 0 & 0 \\
\hline 42 & 204,1 & 5,8 & NW & 2376 & 1506 & 1 & 0 & 0 & 0 \\
\hline 43 & 206,2 & 6,7 & $S$ & 1981 & 2013 & 1 & 0 & 0 & 0 \\
\hline 44 & 159,6 & 21,7 & $\mathrm{~N}$ & 630 & 4401 & 0 & 0 & 0 & 0 \\
\hline 45 & 218,6 & 23,4 & E & 2262 & 1382 & 1 & 0 & 0 & 1 \\
\hline 46 & 229,1 & 21,5 & Flat & 2762 & 808 & 1 & 0 & 0 & 0 \\
\hline 47 & 218,8 & 20,7 & W & 2192 & 156 & 1 & 0 & 0 & 0 \\
\hline 48 & 231,6 & 19,3 & $\mathrm{SE}$ & 2319 & 350 & 0 & 0 & 0 & 1 \\
\hline 49 & 228,3 & 15,7 & $S$ & 2449 & 949 & 0 & 0 & 0 & 1 \\
\hline 50 & 213,9 & 13,0 & SW & 1936 & 1506 & 0 & 0 & 0 & 1 \\
\hline 51 & 211,0 & 0,6 & SW & 2079 & 399 & 0 & 0 & 0 & 0 \\
\hline 52 & 208,7 & 11,9 & $\mathrm{~N}$ & 1981 & 530 & 0 & 0 & 0 & 0 \\
\hline 53 & 211,6 & 0,5 & SW & 2449 & 10 & 1 & 0 & 0 & 0 \\
\hline 54 & 210,9 & 1,3 & NW & 2376 & 65 & 0 & 0 & 0 & 0 \\
\hline 55 & 216,2 & 8,5 & $S$ & 1992 & 555 & 0 & 0 & 0 & 1 \\
\hline 56 & 220,0 & 5,6 & S & 2141 & 105 & 0 & 0 & 0 & 1 \\
\hline 57 & 236,7 & 18,2 & SE & 2079 & 162 & 1 & 1 & 0 & 1 \\
\hline 58 & 241,7 & 6,3 & $\mathrm{NE}$ & 2738 & 440 & 1 & 0 & 0 & 0 \\
\hline
\end{tabular}




\begin{tabular}{|c|c|c|c|c|c|c|c|c|c|}
\hline 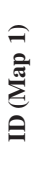 & 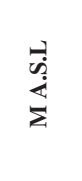 & 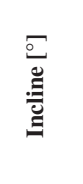 & 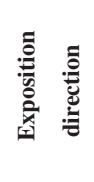 & 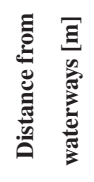 & 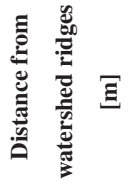 & 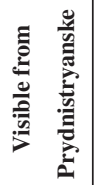 & 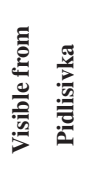 & 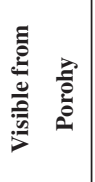 & 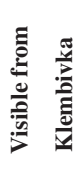 \\
\hline 59 & 236,4 & 23,8 & SE & 2262 & 903 & 1 & 0 & 0 & 1 \\
\hline 60 & 242,2 & 11,0 & $\mathrm{~S}$ & 2738 & 1045 & 0 & 0 & 0 & 1 \\
\hline 61 & 211,8 & 13,4 & $S$ & 1680 & 2176 & 0 & 0 & 0 & 1 \\
\hline 62 & 224,6 & 6,6 & E & 1782 & 432 & 0 & 1 & 0 & 1 \\
\hline 63 & 229,2 & 9,7 & SE & 1640 & 117 & 0 & 0 & 0 & 0 \\
\hline 64 & 166,8 & 2,2 & E & 2232 & 353 & 0 & 0 & 0 & 0 \\
\hline 65 & 171,0 & 8,8 & E & 2079 & 0 & 0 & 0 & 0 & 0 \\
\hline 66 & 180,6 & 13,7 & Flat & 1782 & 62 & 1 & 0 & 0 & 0 \\
\hline 67 & 210,6 & 12,7 & SW & 1485 & 1544 & 1 & 0 & 0 & 0 \\
\hline 68 & 178,1 & 54,7 & Flat & 866 & 699 & 0 & 0 & 0 & 0 \\
\hline 69 & 173,6 & 54,5 & SW & 664 & 557 & 0 & 0 & 0 & 0 \\
\hline 70 & 231,9 & 4,3 & SE & 2449 & 292 & 1 & 0 & 0 & 1 \\
\hline 71 & 231,8 & 3,6 & $S$ & 2458 & 344 & 0 & 0 & 0 & 0 \\
\hline 72 & 241,2 & 8,0 & $\mathrm{~N}$ & 2947 & 0 & 1 & 0 & 0 & 1 \\
\hline 73 & 186,5 & 4,7 & $S$ & 3150 & 224 & 0 & 0 & 0 & 1 \\
\hline 74 & 184,3 & 2,6 & $\mathrm{~N}$ & 3832 & 998 & 0 & 0 & 0 & 1 \\
\hline 75 & 190,4 & 8,2 & NW & 3721 & 372 & 0 & 0 & 0 & 1 \\
\hline 76 & 200,0 & 2,7 & $\mathrm{~S}$ & 2925 & 324 & 1 & 0 & 0 & 1 \\
\hline 77 & 173,5 & 15,2 & $\mathrm{NE}$ & 2271 & 1544 & 0 & 0 & 0 & 0 \\
\hline 78 & 123,2 & 16,6 & $\mathrm{NE}$ & 1640 & 3353 & 0 & 0 & 0 & 0 \\
\hline 79 & 120,9 & 13,9 & $S$ & 2192 & 4031 & 0 & 0 & 0 & 0 \\
\hline 80 & 140,5 & 1,4 & NW & 2856 & 3827 & 0 & 0 & 0 & 0 \\
\hline 81 & 141,4 & 4,3 & SE & 2100 & 4398 & 0 & 0 & 0 & 0 \\
\hline 82 & 143,4 & 6,9 & Flat & 1485 & 4641 & 0 & 0 & 0 & 0 \\
\hline 83 & 146,0 & 63,0 & Flat & 470 & 3712 & 0 & 0 & 0 & 0 \\
\hline 84 & 146,0 & 52,2 & W & 420 & 3513 & 0 & 0 & 0 & 0 \\
\hline 85 & 147,9 & 41,5 & $\mathrm{~N}$ & 630 & 3314 & 0 & 0 & 0 & 0 \\
\hline 86 & 141,0 & 2,1 & S & 2970 & 2810 & 0 & 0 & 0 & 0 \\
\hline 87 & 200,5 & 3,7 & $\mathrm{~S}$ & 2631 & 157 & 1 & 0 & 1 & 1 \\
\hline 88 & 200,9 & 2,5 & $S$ & 1260 & 261 & 1 & 0 & 1 & 1 \\
\hline 89 & 171,1 & 9,3 & S & 1260 & 68 & 0 & 0 & 0 & 0 \\
\hline
\end{tabular}




\begin{tabular}{|c|c|c|c|c|c|c|c|c|c|}
\hline 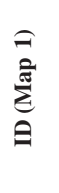 & $\begin{array}{l}\stackrel{+}{\dot{S}} \\
\sum \\
\sum\end{array}$ & 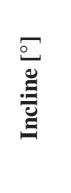 & 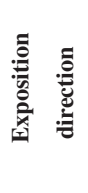 & 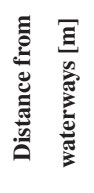 & 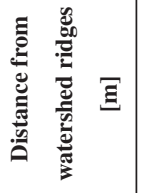 & 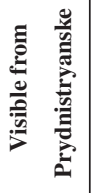 & 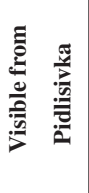 & 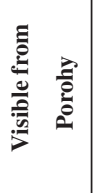 & 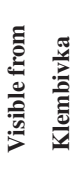 \\
\hline 90 & 107,8 & 47,9 & $\mathrm{E}$ & 757 & 3383 & 0 & 0 & 0 & 0 \\
\hline 91 & 186,7 & 24,5 & Flat & 1071 & 3398 & 0 & 0 & 0 & 0 \\
\hline 92 & 188,5 & 8,2 & $\mathrm{~S}$ & 1680 & 3365 & 1 & 1 & 1 & 1 \\
\hline 93 & 193,1 & 6,4 & S & 1277 & 3864 & 1 & 1 & 1 & 1 \\
\hline 94 & 188,4 & 10,9 & SE & 1224 & 4206 & 0 & 1 & 0 & 1 \\
\hline 95 & 179,5 & 23,4 & E & 1485 & 3764 & 0 & 1 & 0 & 0 \\
\hline 96 & 181,3 & 20,9 & W & 1050 & 3968 & 0 & 0 & 0 & 0 \\
\hline 97 & 179,8 & 16,2 & SW & 757 & 3456 & 0 & 1 & 0 & 0 \\
\hline 98 & 163,7 & 37,0 & $\mathrm{NE}$ & 664 & 3100 & 0 & 0 & 0 & 0 \\
\hline 99 & 191,9 & 1,6 & S & 2394 & 411 & 1 & 1 & 1 & 1 \\
\hline 100 & 191,0 & 4,2 & $S$ & 2529 & 1003 & 1 & 1 & 0 & 1 \\
\hline 101 & 190,3 & 3,4 & SW & 2100 & 1458 & 1 & 1 & 0 & 1 \\
\hline 102 & 181,6 & 15,5 & W & 1470 & 1309 & 0 & 0 & 1 & 1 \\
\hline 103 & 206,4 & 1,9 & SW & 1260 & 1537 & 1 & 0 & 0 & 1 \\
\hline 104 & 206,6 & 0,9 & W & 1260 & 1189 & 0 & 0 & 0 & 1 \\
\hline 105 & 211,2 & 2,6 & $\mathrm{~S}$ & 1599 & 336 & 0 & 0 & 0 & 0 \\
\hline 106 & 211,5 & 1,2 & E & 1794 & 105 & 1 & 0 & 0 & 0 \\
\hline 107 & 210,2 & 3,8 & E & 1328 & 323 & 1 & 0 & 0 & 0 \\
\hline 108 & 203,4 & 6,8 & $\mathrm{NE}$ & 840 & 483 & 1 & 0 & 0 & 0 \\
\hline 109 & 207,4 & 7,4 & W & 2262 & 730 & 0 & 0 & 0 & 0 \\
\hline 110 & 208,8 & 6,1 & SW & 1529 & 1201 & 0 & 0 & 0 & 0 \\
\hline 111 & 201,5 & 7,5 & NW & 1902 & 1816 & 1 & 1 & 0 & 0 \\
\hline 112 & 177,0 & 6,6 & SW & 2100 & 916 & 1 & 0 & 0 & 0 \\
\hline 113 & 168,1 & 19,4 & SW & 2192 & 1407 & 1 & 0 & 0 & 0 \\
\hline 114 & 179,7 & 0,7 & NW & 1936 & 836 & 1 & 1 & 0 & 0 \\
\hline 115 & 179,7 & 0,5 & Flat & 2068 & 1049 & 1 & 1 & 0 & 0 \\
\hline 116 & 179,3 & 0,3 & NW & 1599 & 627 & 1 & 1 & 0 & 0 \\
\hline 117 & 199,7 & 11,0 & $\mathrm{~S}$ & 2100 & 248 & 1 & 1 & 1 & 0 \\
\hline 118 & 199,4 & 24,1 & W & 2192 & 626 & 0 & 0 & 0 & 0 \\
\hline 119 & 200,0 & 6,8 & SE & 1992 & 574 & 0 & 0 & 0 & 0 \\
\hline 120 & 218,7 & 28,7 & S & 3157 & 179 & 1 & 1 & 1 & 1 \\
\hline
\end{tabular}




\begin{tabular}{|c|c|c|c|c|c|c|c|c|c|}
\hline 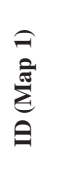 & 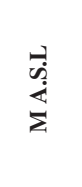 & 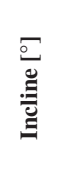 & 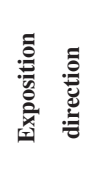 & 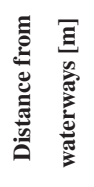 & 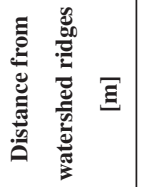 & 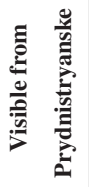 & 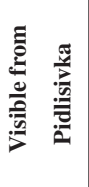 & 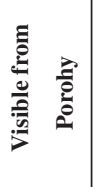 & 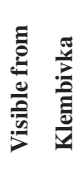 \\
\hline 121 & 217,4 & 15,3 & E & 2940 & 303 & 0 & 0 & 0 & 0 \\
\hline 122 & 200,9 & 2,7 & $S$ & 1514 & 555 & 1 & 1 & 0 & 1 \\
\hline 123 & 202,4 & 4,7 & SW & 3320 & 1052 & 1 & 1 & 0 & 1 \\
\hline 124 & 248,6 & 12,3 & SW & 2068 & 565 & 1 & 1 & 1 & 1 \\
\hline 125 & 253,2 & 6,3 & $S$ & 2917 & 10 & 0 & 0 & 0 & 0 \\
\hline 126 & 250,3 & 12,5 & $\mathrm{~S}$ & 3570 & 105 & 0 & 0 & 0 & 0 \\
\hline 127 & 231,6 & 15,2 & SE & 3564 & 52 & 1 & 0 & 1 & 0 \\
\hline 128 & 199,2 & 15,7 & $\mathrm{~S}$ & 3150 & 373 & 0 & 0 & 0 & 0 \\
\hline 129 & 197,6 & 29,2 & W & 2631 & 1029 & 0 & 0 & 0 & 0 \\
\hline 130 & 188,8 & 8,3 & SE & 1050 & 1944 & 1 & 1 & 0 & 1 \\
\hline 131 & 223,3 & 16,1 & E & 1981 & 562 & 1 & 1 & 0 & 1 \\
\hline 132 & 234,5 & 24,5 & SE & 2537 & 62 & 1 & 1 & 0 & 0 \\
\hline 133 & 238,7 & 15,7 & E & 1732 & 340 & 0 & 0 & 0 & 0 \\
\hline 134 & 223,8 & 7,5 & E & 1485 & 250 & 1 & 1 & 0 & 1 \\
\hline 135 & 226,5 & 1,8 & S & 1260 & 19 & 0 & 0 & 0 & 0 \\
\hline 136 & 272,3 & 8,8 & SW & 1782 & 114 & 1 & 1 & 0 & 0 \\
\hline 137 & 282,7 & 0,9 & $S$ & 4252 & 341 & 0 & 1 & 0 & 1 \\
\hline 138 & 222,6 & 4,5 & SE & 1514 & 259 & 0 & 0 & 0 & 0 \\
\hline 139 & 261,6 & 15,7 & SE & 1981 & 31 & 1 & 1 & 0 & 1 \\
\hline 140 & 263,9 & 7,5 & E & 2100 & 570 & 1 & 1 & 0 & 1 \\
\hline 141 & 233,4 & 9,0 & $S$ & 2376 & 14 & 0 & 0 & 0 & 0 \\
\hline 142 & 239,7 & 13,8 & $\mathrm{~S}$ & 1794 & 810 & 0 & 0 & 0 & 1 \\
\hline 143 & 237,1 & 4,1 & E & 3007 & 69 & 1 & 1 & 0 & 1 \\
\hline 144 & 234,3 & 0,9 & S & 2802 & 14 & 1 & 1 & 0 & 1 \\
\hline 145 & 230,9 & 11,9 & $\mathrm{NE}$ & 2348 & 446 & 1 & 1 & 0 & 0 \\
\hline 146 & 222,3 & 18,8 & E & 2376 & 96 & 0 & 1 & 0 & 0 \\
\hline 147 & 225,4 & 13,6 & SE & 2529 & 259 & 0 & 0 & 0 & 0 \\
\hline 148 & 218,6 & 28,9 & SW & 2520 & 551 & 0 & 0 & 0 & 0 \\
\hline 149 & 231,0 & 11,3 & $\mathrm{~S}$ & 2537 & 543 & 0 & 1 & 0 & 1 \\
\hline 150 & 232,5 & 4,4 & SW & 3007 & 114 & 0 & 0 & 0 & 0 \\
\hline 151 & 218,3 & 14,3 & $\mathrm{NE}$ & 2394 & 899 & 0 & 0 & 0 & 0 \\
\hline
\end{tabular}




\begin{tabular}{|c|c|c|c|c|c|c|c|c|c|}
\hline 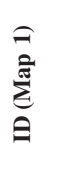 & 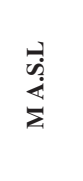 & 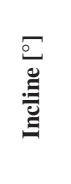 & 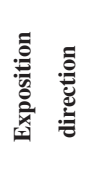 & 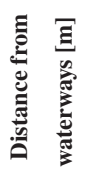 & 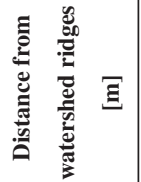 & 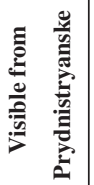 & 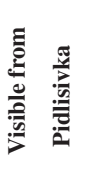 & 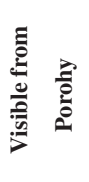 & 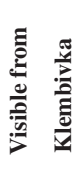 \\
\hline 152 & 216,8 & 23,1 & E & 1936 & 1314 & 0 & 1 & 0 & 0 \\
\hline 153 & 99,5 & 57,1 & $\mathrm{~N}$ & 210 & 1834 & 0 & 0 & 0 & 0 \\
\hline 154 & 254,6 & 8,3 & SE & 1794 & 319 & 0 & 1 & 0 & 0 \\
\hline 155 & 254,8 & 13,6 & SW & 2537 & 78 & 0 & 1 & 0 & 0 \\
\hline
\end{tabular}

Translated by Piotr T. Żebrowski 


\section{REFERENCES}

Jaskulski M., Szmidt A.

2013 Ocena przydatności automatycznego wyznaczania linii szkieletowych terenu do analiz geomorfometrycznych. Folia Geographica Socioeconomica 13: 145-156.

Kośko A. (Ed.)

2015 Podolia as a Cultural Contact Area in the 4th/3rd-2nd Millennium BC, Baltic Pontic Studies 20.

Kusiński W., Zastawnyj F.

2003 Ukraina: przyroda-ludność - gospodarka. Warszawa.

Litwin L., Myrda G.

2005 Systemy informacji geograficznej. Zarządzanie danymi przestrzennymi w GIS, SIP, SIT, LIS. Gliwice.

Makohonienko M., Hildebrandt-Radke I.

2014 Kontekst przyrodniczy i perspektywy studiów paleośrodowiskowych stanowiska kultury jamowej w Pidlisiwce nad Dniestrem, zachodnia Ukraina. In: A. Kośko, M. Potupczyk, S. Razumow (Eds) Naddniestrzańskie kompleksy cmentarzysk kurhanowych społeczności z III $i$ z pierwszej połowy II tysiąclecia przed Chr. w okolicach Jampola, obwód winnicki. Z badań nad północno-zachodnia rubieża osadnictwa społeczności kręu kultur „wczesnobrazowych” strefy pontyjskiej. Badania z lat 1984-2014. Archaeologia Bimaris - Monografie 6, 247-274. Poznań.

Placek A.

2008 Zastosowanie numerycznego modelu terenu w geomorfologii strukturalnej na przykładach z obszaru Sudetów. Landform Analysis 9: 364-368.

Potupczyk M., Razumow S.

2014 Zgrupowanie cmentarzysk kurhanowych w rejonie jampolskim. In: A. Kośko, M. Potupczyk, S. Razumow (Eds) Naddniestrzańskie kompleksy cmentarzysk kurhanowych społeczności z III $i$ z pierwszej połowy II tysiaclecia przed Chr. w okolicach Jampola, obwód winnicki. Z badań nad północno-zachodnią rubieża osadnictwa społeczności kregu kultur „wczesnobrazowych” strefy pontyjskiej. Badania z lat 1984-2014. Archaeologia Bimaris - Monografie 6, 35-40. Poznań. 
Przybyła M.M., Podsiadło M., Potupchyk M., Włodarczak P., Żurkiewicz D.

2017 The Eneolithic ritual barrow complex, Prydnistryanske, Vinnytsia Oblast: magnetometric surveys. Baltic-Pontic Studies 22: 30-40.

Ślusarska K.

2011 Uwagi o uniwersalnym znaczeniu kurhanów w tradycji grzebalnej społeczności wspólnoty katakumbowej wczesnego okresu epoki brązu Nadczarnomorza. In: H. Kowalewska-Marszałek, P. Włodarczak (Eds) Kurhany i obrządek pogrzebowy w IV-II tysiącleciu p.n.e, 131-138. Kraków.

Weathley D.

1995 Cumulative Viewshed Analysis: a GIS-based method for investigating intervisibility, and its archaeological application. In: G. Lock, G. Stan (Eds) Archaeology and GIS: a European perspective, 5-13. London. 